\title{
Nasal, pharyngeal and laryngeal endoscopy procedures during COVID-19 pandemic: available recommendations from national and international societies
}

\author{
Pietro De Luca ${ }^{1,6}$ - Alfonso Scarpa ${ }^{1} \cdot$ Massimo Ralli $^{2} \cdot$ Marco De Vincentiis $^{3} \cdot$ Ettore Cassandro $^{1}$. \\ Giuseppe Chiarella ${ }^{4}$. Claudia Cassandro ${ }^{5}$
}

Received: 14 April 2020 / Accepted: 28 April 2020 / Published online: 6 May 2020

(c) Springer-Verlag GmbH Germany, part of Springer Nature 2020

\section{To the Editor,}

The Severe Acute Respiratory Syndrome-CoronaVirus-2 (SARS-CoV-2), also known as COVID-19, pandemic is engaging clinicians around the world in an unprecedented effort to limit the viral spread and treat affected patients; the rapid diffusion of the disease represents a risk for healthcare providers who have a close contact with the upper aerodigestive tract during medical, diagnostic and surgical procedures [1].

Available evidence from China, Iran, Italy and United States $[2,3]$ suggests that otolaryngology specialists have a considerably high risk of contracting COVID-19 infection due to diagnostic or surgical aerosol-generating procedures (e.g. laryngeal endoscopy), as well as during head and neck emergency or surgical procedures $[4,5]$.

Nasal, pharynx and laryngeal endoscopy represents a high-risk procedure for otolaryngologists as it is commonly used in routine diagnostics, requires a short physical distance between patients and personnel, and can induce sneezing and coughing with consequent potential virus transmission

Pietro De Luca

dr.dlp@hotmail.it

1 Medicine and Surgery, University of Salerno, Salerno, Italy

2 Department of Sense Organs, Sapienza University, Rome, Italy

3 Department of Oral and Maxillofacial Sciences, Sapienza University, Rome, Italy

4 Unit of Audiology and Phoniatrics, Department of Experimental and Clinical Medicine, Magna Græcia University, Catanzaro, Italy

5 Surgical Sciences Department, University of Turin, Turin, Italy

6 Head and Neck Department, University of Salerno, Via G. Maggi 28, Roma, Salerno, Italy through droplets, contact transmission and aerosol transmission especially in cases of long exposure to high concentrations of aerosols in closed environments [2, 5].

For this reason, recommendations for nasal, pharynx and laryngeal endoscopy during COVID-19 pandemic have been published by national and international otolaryngology and head and neck surgery societies.

We conducted a review of the recent literature on endoscopic otolaryngology procedures during COVID-19 pandemic and evaluated available data published until April 15, 2020.

Sixty-six societies have been identified and 27 (40.9\%) of them published information and recommendations regarding nasal, pharyngeal and laryngeal endoscopy procedures during COVID-19 pandemic (Table 1). The majority of societies (24 societies-88.9\%) suggested to perform endoscopy procedures only if strictly necessary; one $(3.7 \%)$ recommended to avoid flexible endoscopy in all cases. Among them, the ENT UK at The Royal College of Surgeons of England suggested to consider whether to use or avoid topical decongestant and local anesthetic solution to reduce chances of sneezing and coughing during examination [6].

There is a lack of consensus about whether flexible or rigid endoscope should be used, while all societies recommended performing endoscopy using a monitor without directly viewing through the eyepiece.

All national and international societies recommended the rational use of personal protective equipment (PPE) during the diagnostic procedures such as disposable gowns, gloves, FFP2 or N95 respirators and surgical masks, and eye protection (goggles or face shield), based on the experience of health care systems in Asia and Europe [1]; endoscopy staff should be protected against infectious material during the endoscopic procedure as well as against direct contact with contaminated equipment or potentially harmful chemicals during the sterilization procedures [7]. Furthermore, 
Table 1 International/National Societies of Otolaryngology and Head and Neck Surgery that published information about nasal, pharyngeal and laryngeal endoscopy during COVID-19 pandemic

\begin{tabular}{l}
\hline Society; country \\
\hline Confederation of European Otorhinolaryngology_Head and Neck \\
Surgery; Europe \\
European Laryngology Society; Europe \\
European Rhinologic Society; Europe \\
European Society of Pediatric Otorhinolaryngology (ESPO); Europe \\
Royal Belgian Society of Oto-Rhino-Laryngology, Head and Neck \\
Surgery; Belgium \\
Bulgarian Rhinologic Society; Bulgaria \\
Czech Society of Otorhinolaryngology and Head and Neck Surgery; \\
Czech Republic \\
Dansk Society of Otorhinolaryngology, Head and Neck Surgery; \\
Denmark
\end{tabular}

ENT UK at The Royal College of Surgeons of England; England

Société Française d'Oto-Rhino-Laryngologie et de Chirurgie de la Face et du Cou, France

Association Française d'ORL Pédiatrique (AFOP); France

Società Italiana di Otorinolaringoiatria e Chirurgia Cervico Facciale; Italy

Società Italiana di Otorinolaringologia Pediatrica, Italy

Società Italiana del Basicranio; Italy

Norsk Forening for Otorhinolaryngologi; Norway

Serbian Head and Neck Society; Serbia

Slovenskà Spolocnost pre Otorinolayngologiu a Chirurgiu Hlavy a

Krku; Slovak Republic

Sociedad Española de Otorrinolaringologia y Cirugía de Cabeza y Cuello; Spain

Schweizerische Gesellschaft für Oto-Rhino-Laryngologie, Hals- und Gesichtschirurgie; Switzerland

Canadian Society of Otolaryngology-Head and Neck Surgery; Canada

American Academy of Otolaryngology Head and Neck Surgery, United States of America

North America Skull Base Society; United States of America

Federacion Argentina de Sociedades de Otorrinolaringología; Argentina

Associação Brasileira de Otorrinolaringologia e Cirurgia CérvicoFacial; Brasile

The Australian Society of Otolaryngology—Head and Neck Surgery; Australia

Philippine Society of Otolaryngology Head and Neck Surgery; Philippine

The South African Society of Otorhinolaryngology Head and Neck Surgery; South Africa
Website (as of April 15, 2020)

https://www.ceorlhns.org/covid-19/ceorl-hns-statement

https://www.elsoc.org

https://www.europeanrhinologicsociety.org/?page_id=2143

https://www.espo.eu.com/news/covid-19-information/

https://orl-nko.be/nl/covid-19

https://www.bulgarianrhinologicsociety.org

https://www.otorinolaryngologie.cz

https://dsohh.dk

https://www.entuk.org/sites/default/files/Nasal\%20endoscopy\%20and $\%$ 20laryngoscopy $\% 20$ examination $\% 20$ of $\% 20$ ENT\%20patients_compr essed $\% 20 \% 281 \% 29$.pdf

https://www.sforl.org/wp-content/uploads/2020/04/Arbre-decisionne 1-COVID-pour-ORL-V10-002.pdf

https://www.sforl.org/wp-content/uploads/2020/04/AFOP-SFORL -COVID-19.pdf

https://www.sioechcf.it/news-covid-19/

https://www.sio-p.it/eventi/36-covid19.html

https://www.societabasicranio.it

https://www.legeforeningen.no

https://www.sld.org.rs/

https://www.sso.sk

https://seorl.net/posicionamiento-de-la-seorl-ccc-sobre-la-pandemia-decoronavirus/

https://www.orl-hno.ch/covid-19.html

https://www.entcanada.org/news-events/covid-19-alerts/

https://www.entnet.org/content/coronavirus-disease-2019-resources

https://www.nasbs.org

https://faso.org.ar/recomendaciones.asp

https://www.aborlccf.org.br/secao_detalhes.asp?s=51\&id=5946

https://www.asohns.org.au

https://pso-hns.org/2020/03/22/endoscopy-guidelines-during-covid -19-pandemic/

https://docs.mymembership.co.za/docmanager/41bfc900-b208-47bb8517-69aa8219597e/00149202.pdf removal of PPE is a high-risk task and great care must be taken not to contaminate self or others during this process [1]. No society recommended adopting post-exposure prophylaxis in physician or in healthcare workers.
All international societies encouraged to follow standardized sterilization procedures for endoscopes [8]. Sterilization should always be performed immediately after finishing the procedure; the disinfection and reprocessing of the 
endoscope and instruments used for a patient with COVID19 are similar to those used in standard practice [9].

Although the COVID-19 situation is evolving fast and these society statements are subject to change over time, we suggest following these recommendations about execution, sterilization and personal protection for endoscopy procedures during COVID-19 pandemic for all healthcare workers in otolaryngology units.

\section{Compliance with ethical standards}

Conflict of interest The authors declare that they have no conflict of interest.

Research involving human participants and/or animals Not applicable.

Informed consent Not applicable.

\section{References}

1. Givi B, Schiff BA, Chinn SB, Clayburgh D, Iyer NG, Jalisi S, Moore MG, Nathan CA, Orloff LA, O'Neill JP, Parker N, Zender C, Morris LGT, Davies L (2020) Safety recommendations for evaluation and surgery of the head and neck during the COVID19 pandemic. JAMA Otolaryngol Head Neck Surg. https://doi. org/10.1001/jamaoto.2020.0780

2. Wang J, Du G (2020) COVID-19 may transmit through aerosol. Ir J Med Sci. https://doi.org/10.1007/s11845-020-02218-2

3. Arshad Ali S, Baloch M, Ahmed N, Arshad Ali A, Iqbal A (2020) The outbreak of Coronavirus Disease 2019 (COVID-19)—an emerging global health threat. J Infect Public Health. https://doi. org/10.1016/j.jiph.2020.02.033
4. Balakrishnan K, Schechtman S, Hogikyan ND, Teoh AYB, McGrath B, Brenner MJ (2020) COVID-19 pandemic: what every otolaryngologist-head and neck surgeon needs to know for safe airway management. Otolaryngol Head Neck Surg. https://doi. org/10.1177/0194599820919751

5. Kowalski LP, Sanabria A, Ridge JA, Ng WT, de Bree R, Rinaldo A, Takes RP, Makitie AA, Carvalho AL, Bradford CR, Paleri V, Hartl DM, Vander Poorten V, Nixon IJ, Piazza C, Lacy P, Rodrigo JP, Guntinas-Lichius O, Mendenhall WM, D'Cruz A, Lee AWM, Ferlito A (2020) COVID-19 pandemic: effects and evidence-based recommendations for otolaryngology and head and neck surgery practice. Head Neck. https://doi.org/10.1002/hed.26164

6. ENTUK-The Royal College of Surgeons of England (2020) Nasal endoscopy and laryngoscopy examination of ENT patients

7. Beilenhoff U, Biering H, Blum R, Brljak J, Cimbro M, Dumonceau JM, Hassan C, Jung M, Kampf B, Neumann C, Pietsch M, Pineau L, Ponchon T, Rejchrt S, Rey JF, Schmidt V, Tillett J, van Hooft JE (2018) Reprocessing of flexible endoscopes and endoscopic accessories used in gastrointestinal endoscopy: Position Statement of the European Society of Gastrointestinal Endoscopy (ESGE) and European Society of Gastroenterology Nurses and Associates (ESGENA) —update 2018. Endoscopy 50(12):12051234. https://doi.org/10.1055/a-0759-1629

8. Kramer A, Kohnen W, Israel S, Ryll S, Hubner NO, Luckhaupt H, Hosemann W (2015) Principles of infection prevention and reprocessing in ENT endoscopy. GMS Curr Top Otorhinolaryngol Head Neck Surg. https://doi.org/10.3205/cto000125

9. Chiu PWY, Ng SC, Inoue H, Reddy DN, Ling HuE, Cho JY, Ho LK, Hewett DG, Chiu HM, Rerknimitr R, Wang HP, Ho SH, Seo DW, Goh KL, Tajiri H, Kitano S, Chan FKL (2020) Practice of endoscopy during COVID-19 pandemic: position statements of the Asian Pacific Society for Digestive Endoscopy (APSDECOVID statements). Gut. https://doi.org/10.1136/gutjnl-2020321185

Publisher's Note Springer Nature remains neutral with regard to jurisdictional claims in published maps and institutional affiliations. 